\title{
Identification of a novel imprinting mechanism at the X-linked imprinted locus, $X$-linked Lymphocyte Regulated 3/4 (XIr3/4)
}

\author{
Sohaib M Qureshi", Michael B Murphy, Seth Kasowitz, Robert J Foley, Michael J O'Neill \\ From Epigenetics and Chromatin: Interactions and processes \\ Boston, MA, USA. 11-13 March 2013
}

\section{Background}

Genomic imprinting is the epigenetic process by which a subset of genes is expressed from only one allele based on the parent of origin. To date there are approximately 150 confirmed autosomal imprinted loci in the mammalian genome. The epigenetic hallmark of an autosomal imprinted locus is the presence of differential methylation at CpG islands otherwise known as a DMR[1]. Imprint maintenance at autosomal loci is accomplished through specific histone modifications[2]. In 2005, Raefski et.al. found the first X-linked imprinted locus, $X l r 3 / 4$ of which three paralogs, $X l r 3 b / 4 b / 4 c$, were maternally expressed and paternally silenced in mouse neonatal brain[3]. Here we use a series of techniques to uncover the imprinting mechanism at the $X l r$ locus using known autosomal imprinting mechanisms as a model.

\section{Materials and methods}

Mice were generated that either carried the maternal (39, $\mathrm{X}^{\mathrm{m}}$ ) or paternal $\left(39, \mathrm{X}^{\mathrm{p}}\right) \mathrm{X}$ chromosome. To measure the difference in both primary transcript and mRNA levels of $X l r 3 b / 4 b / 4 c$ between these samples quantitative real time PCR was performed. To search for differential methylation, MeDIP followed by hybridization to an X chromosome tiling array was performed for a global view of methylation at the $\mathrm{Xlr} 3 / 4$ locus. For confirmation, targeted bisulfite sequencing was performed at $\mathrm{CpG}$ islands. Chromatin Immunoprecipitation (ChIP) followed by real time PCR was used to assess differential enrichment of H3K4me3, H3K27me3, H3K9me2, and H3K36me3 at $X l r 3 b$. Furthermore, ChIP-Seq was performed to trace RNA Polymerase II (PolII) and H3K36me3 across the Xlr3/4 locus.

Genetics and Genomics, University of Connecticut, Storrs, CT 06066, USA

\section{Results}

We show that there is no differential methylation at the $X \operatorname{lr} 3 / 4$ locus between $39, \mathrm{X}^{\mathrm{m}}$ and $39 \mathrm{X}^{\mathrm{P}}$ samples. Potential candidate regions for differential methylation according to MeDIP assays were disproven by bisulfite sequencing of $\mathrm{CpG}$ islands within those regions. Furthermore, all regions assayed at $X l r 3 b$ were hypermethylated on both alleles. We show that H3K4me3 and H3K27me3 are not enriched at either allele of $X l r 3 b$ while $\mathrm{H} 3 \mathrm{~K} 9 \mathrm{me} 2$ is equally enriched on both. We show that the primary transcript of $X l r 3 b$ only shows imprinted expression at the 3' end of the gene and this is confirmed by PolII enrichment indicating a stall on the paternal allele during transcriptional elongation. Lastly, H3K36me3 enrichment mirrors that of RNA PolII.

\section{Conclusions}

We show that there is no DMR to govern gene expression at the $X l r 3 / 4$ locus and thus a novel mechanism must exist to regulate the imprint. The current model for this mechanism involves PolII stalling during transcriptional elongation along the paternal allele of $X l r 3 b$. On the maternal allele PolII transcribes through the 3'end of the gene unimpeded. While the cause of the stall remains unknown it may involve H3K36me3 histone methyltransferases.

Published: 18 March 2013

\section{References}

1. Reik W, Collick A, Norris ML, Barton SC, Surani MA: Genomic imprinting determines methylation of parental alleles in transgenic mice. Nature 1987, 328(6127):248-251.

2. Verona Rl, Thorvaldsen $J \mathrm{~L}$, Reese $\mathrm{K}$, Bartolomei MS: The transcriptional status but not the imprinting control region determines allele-specific histone modifications at the imprinted $\mathrm{H} 19$ locus. Mol Cell Biol 2008, 28(1):71-82.

(c) 2013 Qureshi et al; licensee BioMed Central Ltd. This is an Open Access article distributed under the terms of the Creative Commons Attribution License (http://creativecommons.org/licenses/by/2.0), which permits unrestricted use, distribution, and reproduction in any medium, provided the original work is properly cited. 
3. Raefski AS, O'Neill MJ: Identification of a cluster of X-linked imprinted genes in mice. Nat Genet 2005, 37(6):620-624

doi:10.1186/1756-8935-6-S1-P68

Cite this article as: Qureshi et al:: Identification of a novel imprinting

mechanism at the X-linked imprinted locus, $X$-linked Lymphocyte

Regulated 3/4 (XIr3/4). Epigenetics \& Chromatin 2013 6(Suppl 1):P68.

Submit your next manuscript to BioMed Central and take full advantage of:

- Convenient online submission

- Thorough peer review

- No space constraints or color figure charges

- Immediate publication on acceptance

- Inclusion in PubMed, CAS, Scopus and Google Scholar

- Research which is freely available for redistribution

Submit your manuscript at www.biomedcentral.com/submit

() BioMed Central 